\title{
Penerapan Teknologi Mesin Pencacah Sampah Organik Rumah Tangga di Desa Pesucen Kabupaten Banyuwangi
}

\author{
Ninik Sri Rahayu' ${ }^{1}$, Abdul Rohman², Khairul Muzaka ${ }^{2 *}$ \\ 1 Teknologi Pengolahan Hasil Ternak, Politeknik Negeri Banyuwangi, Banyuwangi, Indonesia \\ 2 Teknik Mesin, Teknik Manufaktur Kapal, Politeknik Negeri Banyuwangi, Banyuwangi, Indonesia \\ Email: ${ }^{1}$ ninikrahayu@poliwangi.ac.id,2rahmanabd@poliwangi.ac.id, 3,"zaka@poliwangi.ac.id
}

\begin{abstract}
Abstrak-Saat ini banyak sekali di lingkungan sekitar terdapat sampah yang berserakan, seperti hal nya sampah yang terdapat disungai kecil yang di karenakan kurang kesadarannya masyarakat yang membuang sampah disungai. Padahal membuang sampah disungai menyebabkan meluapnya air sungai sehingga ada terjadinya banjir.Untuk mengatasi masalah lingkungan tersebut, maka diciptakanlah sebuah alat yaitu tong pencacah sampah organik rumah tangga, mesin ini adalah salah satu solusi untuk mengurangi pembuangan sampah di sungai, yang kemudian hasil pencacahan tersebut digunakan untuk pupuk organik bagi tanaman.Perencanaan mesin tong pencacah sampah organik rumah tangga sebagai solusi bagi lingkungan untuk pembuatan bahan pupuk organik juga untuk mengurangi sampah yang dibuang sembarang, dan juga hasil pencacahan tersebut digunakan untuk pupuk organik pada tanaman. Program pengabdian masyarakat ini melibatkan mitra dan mahasiswa Program Studi Teknik Mesin. Tahap awal kegiatan pengabdian ini adalah melakukan survey untuk mengidentifikasi permasalahan yang dihadapi oleh mitra dan melakukan studi literatur untuk mendapatkan solusi atas permasalahan mitra. Setelah solusi permasalahan mitra didapatkan, langkah selanjutnya melakukan perancangan dan pembuatan mesin yang dibutuhkan yaitu mesin pencacah sampah organik rumah tangga. Mesin pencacah sampah organik rumah tangga yang ditransfer ke mitra dibuat sesederhana mungkin, mudah dioperasikan dan mudah dalam proses perawatannya. Dengan adanya mesin pencacah sampah organik ini diharapkan dapat membantu masyarakat Desa Pesucen dalam miminimalisir tumpukan sampah organik yang berdampak buruk bagi lingkungan.
\end{abstract}

.Kata Kunci: Sampah; Pupuk; Organik; Alat Pencacah

\begin{abstract}
Currently, there is a lot of garbage scattered around in the environment, such as the garbage found in small rivers due to the lack of awareness of people who throw garbage in rivers. In fact, throwing garbage in the river causes the overflow of river water so that there is a flood. To overcome these environmental problems, a tool was created, namely the household organic waste chopper, this machine is one solution to reduce waste disposal in the river, which then the results of the enumeration are used for organic fertilizers for plants. Planning for household organic waste choppers as a solution for the environment for the manufacture of organic fertilizer materials as well as to reduce waste that is thrown away, and also the results of the enumeration are used for organic fertilizer on plants. This community service program involves partners and students of the Mechanical Engineering Study Program. The initial stage of this service activity is to conduct a survey to identify the problems faced by partners and conduct a literature study to obtain solutions to partner problems. After the solution to the partner's problem is obtained, the next step is to design and manufacture the machine needed, namely a household organic waste chopper. The household organic waste shredder which is transferred to partners is made as simple as possible, easy to operate and easy to maintain. With the existence of this organic waste shredder, it is hoped that it can help the Pesucen Village community in minimizing piles of organic waste that have a negative impact on the environment.
\end{abstract}

Keywords: Garbage; Fertilizer; Organic; Chopper

\section{PENDAHULUAN}

Dalam menjalankan aktivitasnya, manusia mengasilkan barang sisa yang tidak dipakai lagi berupa sampah. Sampah merupakan limbah dari manusia ataupun masyarakat yang kebanyakan dibuang sembarangan ke alam, hal tersebut dikarenakan tingkat kesadaran masyarakat yang rendah akan kelestarian alam, sehingga akan berdampak terhadap kesehatan lingkungan yang berakibat negative terhadap tumbuhan, binatang maupun manusia itu sendiri. Sebagian dari sampah tersebut yang berupa sampah anorganik sulit sekali terurai, hingga butuh tahunan bahkan ratusan tahun untuk bisa mengurainya di alam. Adapun bentuk limbah yang sering dibuang sembarangan dialam antara lain padat, cair, gas ataupun pasta.

Kegiatan membuang sampah sebarang tersebut juga banyak dilakukan masyarakat desa yang tinggal di hulu sungai yang hilirnya terdapat dikota sehingga selain mengakibatkan pencemaran lingkungan juga akan mengakibatkan banjir di daerah perkotaan yang letaknya di hilir sungai.

Sampah organik dapat merusak kelestarian lingkungan juga menggangu kesehatan masyarakat. Pencemarannya yang bisa melalui udara, air, tanah, maupun kontak dengan organisme lain yang dapat menimbulkan penyakit. Dampak dari sampah organik tersebut juga dapat menimbulkan bau tidak sedap sehingga mengganggu aktivitas bagi masyarakat sekitar serta meningkatnya penyakit yang dibawa oleh nyamuk, tikus hingga lalat. Oleh karena itu, penting bagi kita menjaga kebersihan dan kelestarian lingkungan. Untuk mewujudkan hal tersebut, banyak komunitas, unit usaha maupun kegiatan sosial masyarakat di Kabupaten Banyuwangi mulai mengadakan program yang berkaitan dengan kebersihan lingkungan dan pengelolahan sampah yang kondisi sekarang ini sangat memprihatinkan dimana masyarakat membuang sampah sembarangan. Salah satu cara untuk mengurangi dampak resiko sampah adalah dengan menguraikan sampah menjadi sesuatu yang berguna bagi masyarakat. Akan tetapi hal itu sulit dilakukan jika tanpa adanya bantuan mesin pencacah 
sampah. Program penanganan sampah antara lain dengan pengolahan sampah organik limbah dari rumah tangga menggunakan alat pencacah sampah organic, sehingga mempercepat proses decomposisi menjadi pupuk organik, yang pada akhirnya akan memberi nilai tambah sampah menjadi bernilai ekonomis.

\section{METODE PELAKSANAAN}

Kegiatan pengabdian masyarakat ini dilaksanakan di Dusun Kerajan RT.01/01 Desa Pesucen, Kecamatan Kalipuro, Kabupaten Banyuwangi Jawa Timur dengan jarak sekitar 23 km dari Politeknik Negeri Banyuwangi. Secara garis besar pelaksanaan pengabdian masyarakat ini dibagi menjadi beberapa tahapan antara lain sebagai berikut:

1. Survey Lapangan ke Mitra

Survey lapangan bertujuan untuk mengidentifikasi permasalahan yang dihadapi oleh mitra. Berdasarkan survey yang telah dilaksanakan, sampah yang dibuang begitu saja dan tidak terkelola menjadi penyebab kurangnya kualitas lingkungan di Desa Pesucen, Kecamatan Kalipuro.

2. Diskusi Dengan Mitra dan Mencari Pemecahan Masalah

Diskusi dengan mitra dilakukan dengan tujuan untuk mencari solusi atas permasalahan yang dihadapi oleh mitra terkait mesin pencacah sampah. Berdasarkan hasil diskusi, didapatkan bahwa Pemdes Pesucen membutuhkan mesin pencacah sampah yang dapat digunakan untuk pembuatan pupuk organik. Solusi yang ditawarkan pada program pengabdian masyarakat ini adalah dengan membuatkan mesin pencacah sampah organik rumah tangga sehingga dapat membantu Pemdes Pesucen dalam mengurangi tumpukkan limbah organik rumah tangga.

3. Perancangan Alat

Mesin pencacah sampah organik rumah tangga ini proses pembuatannya dilakukan di workshop pemesinan dan pengelasan Jurusan Teknik Mesin Politeknik Negeri Banyuwangi.

4. Pelatihan Pengoperasian Mesin

Setelah mesin pencacah sampah organik rumah tangga di uji coba, langkah selanjutnya adalah memberikan pelatihan pengoperasian alat dan perwatan mesin ke mitra.

\section{HASIL DAN PEMBAHASAN}

Kegiatan Pengabdian Kepada Masyarakat (PKM) tahun 2021 ini dilaksanakan di Desa Pesucen yang masuk di Kecamatan Kalipuro Kabupaten Banyuwangi, posisi desa ini terletak disebelah barat kota Banyuwangi dengan jarak sekitar $11 \mathrm{Km}$ dengan ketinggian sekitar $290 \mathrm{~m}$ diatas permukaan laut dan suhu rata - rata sekitar $29^{\circ} \mathrm{C}$ dengan curah hujan sekitar 250mm. Desa Pesucen mempunyai luas wilayah sekitar $3 \mathrm{~km}^{2}$ dengan jumlah penduduk sekitar 4500 Jiwa.

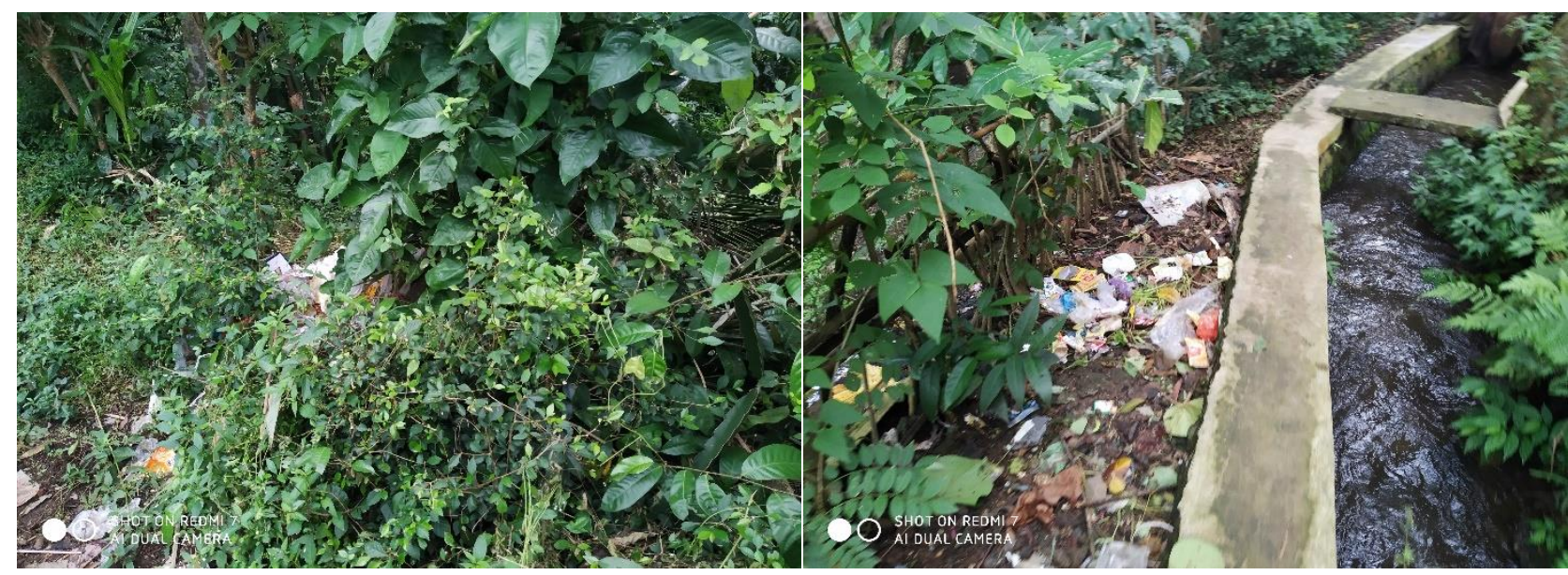

Gambar 1. Sampah limbah rumah tangga

Dengan jumlah penduduk yang cukup besar tersebut mengakibatkan banyaknya limbah rumah tangga baik sampah organic maupun sampah anorganik seperti plastic yang sulit terurai, hal tersebut membuat polusi udara maupun ditanah dan air karena kebanyakan sampah tersebut dibakar ataupun dibuang di tepi sungai ( seperti yang ditunjukkan pada gambar 1) karena belum ada tempat pengolahan sampah, sehingga dengan kondisi ini menjadi target untuk kegiatan PKM Politeknik Negeri Banyuwangi.

Guna mengatasi permasalahan sampah tersebut, maka kebiatan PKM ini membuat mesin pencacah sampah organic guna mempercepat proses penguraian sampah organic menjadi kompos yang nantinya dimanfaatkan sebagai pupuk organic pada tanaman buah dalam pot (tambulapot) dan tanaman sayur dalam pot (tasapot)guna 


\section{Journal of Social Responsibility Projects by Higher Education Forum}

Vol 2, No 2, November 2021, Page 73-76

ISSN 2723-1674 (Media Online)

meningkatkan taraf hidup masyarakat untuk bangkit dari keterpurukan ekonomi akibat pandemic Covid 19. Dari kegiatan PKM tersebut dihasilkan alat pencacah sampah organic dengan proses antara lain:

\subsection{Proses Pembuatan Pencacah Sampah Organik}

Proses pembuatan alat Pencacah Sampah Organik pada kegiatan pengabdian kepada masyarakat ini dilakukan di Lab CNC Jurusan Teknik Mesin Politeknik Negeri Banyuwangi, seperti yang ditunjukkan pada gambar 2.

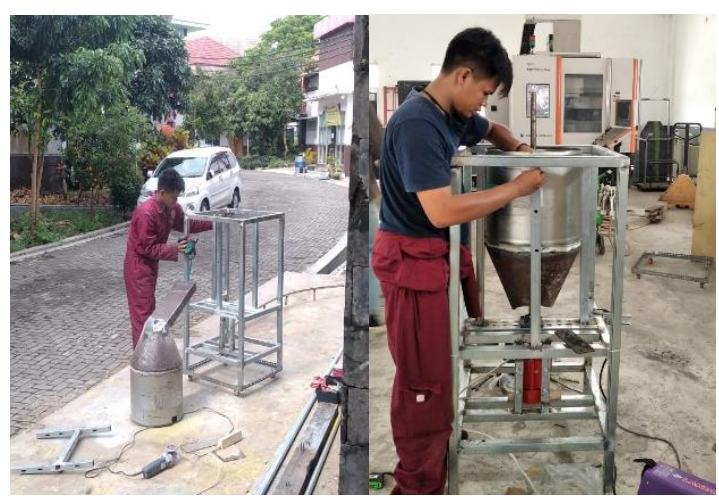

Gambar 2. Proses Pembuatan Alat Pencacah Sampah Organik

\subsection{Alat Pencacah Sampah Organik}

Dalam kegiatan Pengabdian Kepada Masyarakat (PKM) ini telah dibuat alat pencacah sampah organik seperti diperlihatkan pada gambar 3 beserta hasil pencacahannya. Adapun spesifikasi alat antara lain: Daya 0,186 kw, tegangan listrik 220V, kapasitas $87,59 \mathrm{~kg} / \mathrm{jam}$

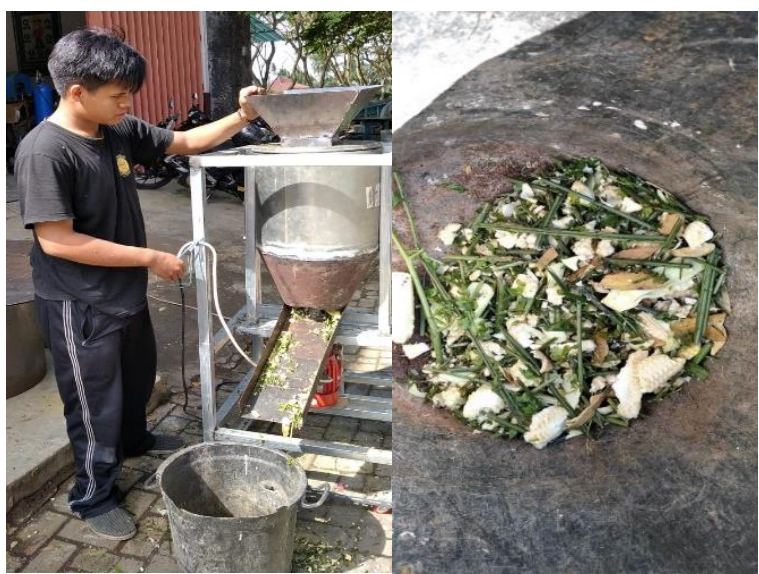

Gambar 3. Alat Pencacah Sampah dan Hasil Cacahannya

\subsection{Serah Terima Alat Pencacah Sampah Organik}

Alat pencacah sampah organic limbah rumah tangga ini telah diserahkan kepada mitra yaitu ketua RT.02/02 Desa Pesucen, Kecamatan Kalipuro, Kabupaten Banyuwangi melalui kegiatan serah terima di Balai Desa Pesucen yang dihadiri oleh Kepala Desa, sekaligus menyelaraskan kegiatan pengabdian masyarakat ini dengan kegiatan desa secara berkesinambungan. Adapun kegiatan pemaparan pengolahan sampah dengan menggunakan alat pencacah sampah yang dibuat dapat dilihat pada gambar 4 dan serah terima alat ditunjukkan pada gambar 5 .

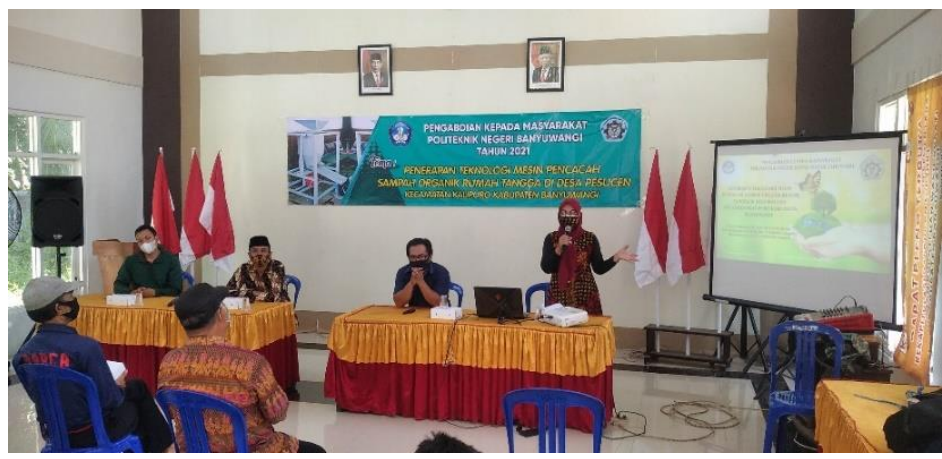

Gambar 4. Pemaparan pengolahan sampah organic dengan alat pencacah sampah 


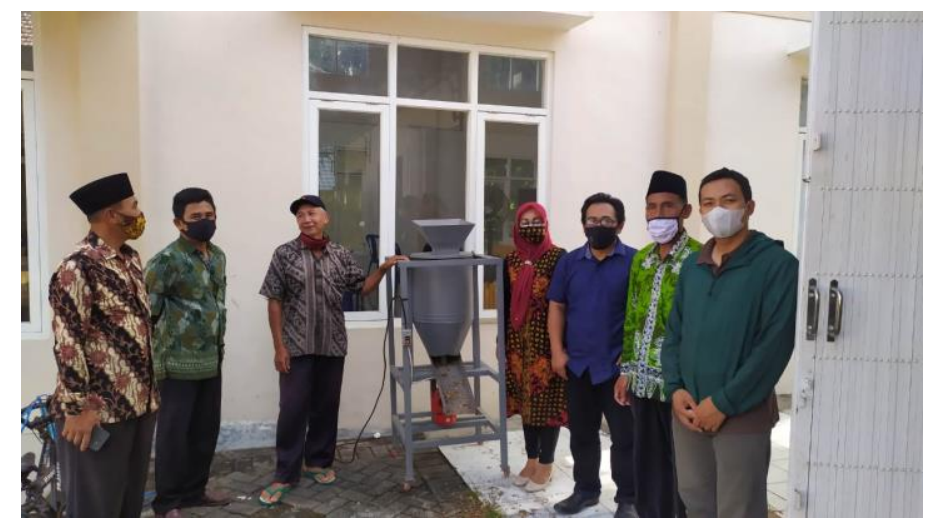

Gambar 5. Serah Terima Alat Pencacah Sampah

Setelah kegiatan serah terima alat pencacah sampah organic rumah tangga, tindak lanjutnya adalah aplikasi dengan pembuatan kompos ataupun pupuk organic dengan pemrosesan sampah organik dengan mesin pencacah tersebut, kemudian proses pengkomposan ( penguraian) sampah hingga menjadi pupuk organic.

\section{KESIMPULAN}

Berdasarkan kegiatan pengabdian yang dilakukan disimpulkan bahwa telah dihasilkan alat yang telah jadi $100 \%$ berupa alat pencacah sampah organic limbah rumah tangga dengan spesifikasi antara lain: a. Daya 0,186 kw , tegangan listrik $220 \mathrm{~V}$, kapasitas $87,59 \mathrm{~kg} / \mathrm{jam}$. Sangat tingginya partisipasi masyarakat dalam pelaksanaan kegiatan pengabdian ini yang ditunjukan dengan tingkat kehadiran yang tinggi dalam sesi pemaparan, pelatihan dan serah terima alat. Alat pencacah sampah organic ini sangat bermanfaat dalam mengurangi jumlah sampah yang dibuang sembarangan dan memberi nilai tambah pada sampah organic menjadi pupuk yang sangat bermanfaat. Dalam kegiatan pengabdian kepada masyarakat ini terdapat beberapa diantaranya perlu pembinaan secara berkesinambungan pada mitra, sehingga alat pencacah sampah organic ini dapat terus bermanfaat serta penyelarasan pengabdian kepada masyarakat dengan program pengembangan yang ada di desa sangat diperlukan, guna memperluas gerakan pengolahan sampah organic ini.

\section{UCAPAN TERIMA KASIH}

Tim dari Kegiatan Pengabdian Kepada Masyarakat (PKM) tahun 2021 ini, mengucapkan terima kasihsebesar-besarnya kepada :

1. Politeknik Negeri banyuwangi yang telah membiayai kegiatan PKM ini sesuai dengan kontrak no: 2674.58/PL36/PG /2021.

2. P3M Politeknik Negeri Banyuwangi yang telah menyiapkan dan mengjoordinir semua kegiatan pengabdian masyarakat ini sehingga berjalan dengan lancer.

3. Kepala desa Pesucen, dan juga Ketua RT.01/02 yang telah memfasilitasi dan menjadi mitra dalam mensukseskan kegiatan Pengabdian Kepada Masyarakat ini.

\section{DAFTAR PUSTAKA}

Abdihu, Y. N. (2016). Perancangan Kampanye Sosial Mengenai Dampak Pembakaran Sampah Di Ruang Terbuka. Universitas Katolik Soegijapranata.

Antu, E. S., \& Djamalu, Y. (2018). Desain Mesin Pencacah Sampah Organik Rumah Tangga Untuk Pembuatan Pupuk Kompos. Jurnal Teknologi Pertanian Gorontalo (JTPG), 3(2), 57-65.

Efendy, W. Y. (2016). Redesain Mesin Pencacah Sampah Organik Hemat Energi Listrik Bagian Dinamis. Politeknik Negeri Banyuwangi.

Hendry, H., Butar, F. B., Situmorang, J. C., Pane, R. M. T. S., Silaen, A. H., Valdano, O., \& Aryza, S. (2019). Peningkatan Efisiensi dan Performa Motor Listrik Berbasiskan PID dan Fuzzy. Seminar Nasional Teknologi Komputer \& Sains (SAINTEKS), 1(1).

Karo, Y. T. B. (2009). Pengelolaan Sampah Rumah Tangga di Kelurahan Sidorame Timur Kecamatan Medan Perjuangan Kota Medan. Universitas Sumatera Utara.

L. Mott, (1985). Machine Elements in Mechanical Design. University of Dayton. Yogyakarta, (1).

Sularso \& Suga, K. (1978). Dasar Perencanaan dan Pemilihan Elemen Mesin. In Jakarta: PT Pradnya Paramita.

Utomo, B. G. (2012). Proses Pembuatan Pisau Pada Mesin Perajang Sampah. Fakultas Teknik Universitas Negeri Yogyakarta. 